\title{
Tebrizli Şair Kerim Meşruteçi Sönmez ve "İsa'nın Son Şamı": Hayatı, Fikrî ve Edebî Kişiliği
}

Merve Erşahin*

Öz

İran'da doğmuş ve yetişmiş olan Kerim Meşruteçi (Sönmez), 20. yüzyılın İran'ında değişen toplum düzeninin içerisinde yaşamış ve yazdığ 1 şiirlerinde birey ve halk sorunlarına değinmiştir. Özellikle İran'da yaşayan Azerbaycan Türklerinin 1979 İran İslam Devrimi sonrası bürokratik ve toplumsal sorunlarına ayna tutmuştur. Sönmez sanatı aracılığıyla fikrî mücadelenin bir parçası olarak edebî alanda toplum adına kendisini ifade etmiştir. İsa'nın Son Şamı, şairin diğer eserleri gibi İran Devrim'i sonrasi gelen dildeki kısmi serbestlikle Arap harfli olarak Azerbaycan Türkçesinde kaleme alınmıştır. Verdiği eserleri, günümüze çok daha yakın bir zamanda gün yüzüne çıkmış ve okurla buluşabilmiştir. Onun şair olarak tanınmasında rol oynayan ve edebî sahada yankı bulmasını sağlayan İsa'nın Son Şamı adlı eserinin anlam evreni üzerinden hareketle okura yeni pencereler açılmaya çalışılacak; devrim zamanı ve sonrasının halk üzerindeki etkileri ve şairin bu dönemle şekillenen düşünce hayatından kalemine yansımaları üzerinde durulacaktır.

Anahtar Kelimeler: Kerim Meşruteçi, İsa'nın Son Şamı (Akşam Yemeği), L. Da Vinci, İran Türkleri, Azerbaycan

Lisans Mezunu, Ankara Üniversitesi, Dil ve Tarih-Coğrafya Fakültesi , Çağdaş Türk Lehçeleri ve Edebiyatları Bölümü, merve.kargali@gmail.com, ORCID: 0000-00015429-5113 


\title{
Tabriz Poet Kerim Meşruteçi Sönmez and "Last Supper of Jesus": His Life, Intellectual and Literary Personality
}

Merve Erşahin*

\begin{abstract}
Karim Mashrutachi (Sönmez), who was born and raised in Iran, lived in the changing social order of the 20th century in Iran, and touched upon the individual and public problems in his poems. In particular, it mirrored the burocratic and social problems of the Azerbaijan Turks living in Iran after the Iran Islamic Revolution of 1979Sonmez expressed himself in the name of society in the literary field as part of the intellectual struggle through his art. Like the other works of the poet, the Last Damascus of Jesus was written in Azerbaijani Turkish with partial freedom in the language following the Iranian Revolution. However, his works came to the surface much more recently and met with the reader. New windows will be opened to the reader through the meaning universe of Last Supper of Jesus, which plays a role in his recognition as a poet and allows him to find an echo in the literary field; The effects of the time and the post-revolution on the people and the reflections of the poet from his thought life shaped by this period will be emphasized.
\end{abstract}

Keywords: Karim Mashrutachi, Last Supper of Jesus, L. da Vinci, Iranian Turks, Azerbaijan

Bachelor's Degree, Ankara University, Faculty of Language, History and Geography, Department of Modern Turkish Dialects and Litaretures, merve.kargali@gmail.com, ORCID: 0000-0001-5429-5113 


\section{Giriş}

İran Türklerinin çağdaş şairlerinden olan Kerim Meşruteçi (Sönmez)'in İsa'nın Son Şamı adlı eserinden hareketle şairin fikrî ve edebî yönünü ele alarak onun ve içinde yaşamış olduğu toplumun hafizasında yer edinmiş ve bugüne kadar taşınmış olan 1979 İran İslam Devrimi ve sonrasındaki devlet-toplum ilişkisinin, şairin sanatındaki yerine değinilecektir.

Bu çalışmaya konu olmuş olan İsa'nın Son Şamı adlı şiir de buradan hareketle firça darbeleri ile yaratılmış ünlü ressam Leonardo Da Vinci'nin meşhur tablosu Son Akşam Yemeği'nin dizelere dil ile aksettirilmiş hâlidir. Çağdaş Azerbaycan Edebiyatı şairi Kerim Meşruteçi Sönmez, Da Vinci'nin tablosuna lirik bir şiirden öte felsefî bir boyut kazandırmıştır. Üzerine titizlik ile düşündüren bu şiirin edebî tahlili kanıksanandan da ileri bir amaç taşımaktadır. İsa'nın Son Şamı'nın analizi ile aktarılmak istenen düşünce ve duyguları kavramaya çalışılacak; Sönmez'in bu düşüncelerini nasıl ifade ettiğine, hislerini Azerbaycan Türkçesinin sunduğu imkânlar dâhilinde bize nasıl aktardığına temas edilecektir.

İsa'nın Son Şamı adlı eserin tahlilinde başvurulan nihaî kaynak şairin 2016 (1395) yılında yeniden basılmış olan kitabıdır. Bu eser Arap harfli olarak Azerbaycan Türkçesinde yazılmıştır. Eserin analizi için şiirden alınan örnekler, Latin harfli trankripsiyon olarak verilecektir. Azerbaycan edebiyat1 ürünlerinde "poema" olarak alandırılan türde yazılmış olan eser Türk edebiyatındaki "manzume" ile örtüşmektedir. Dolayısı ile betimlemede kullanılan yöntem, Azerbaycan edebiyatı nazım türlerinden karşılaştırmalı olarak yararlanılması ile gerçekleştirilmiştir.

Verilerin toplanmasına ilişkin bir sonraki adımda şair ile iletişime geçilmiş olup, otobiyografisi ve eserine ilişkin görüşleri de kaynak olarak edinilmiştir. Eserin ilk basımından itibaren okur ve eleştirmenler tarafından ilgi ve görüsslerin dâhil edildiği yazı, makale, gazete ve dergi yazıları incelenmiştir.

Bu çalışma, üç ana bölüm üzerinden incelenecektir. İlk olarak Sönmez'in bizzat kendisi tarafından kaynaklık ettiği hayatı ve İsa'nın Son Şamı adlı eserinin analizi üzerinde durulacaktır. İkinci bölüm ise Sönmez'in fikrî ve edebî kişiliğinin tahlilinden oluşacaktır. Son olarak da bu çalışmanın üçüncü bölümü olan sonuç kısmında Tebriz'den tüm Türk dünyasına hitap eden 
şairin iletmek istediği mesajı çözümlemeye ve Türk dili edebî sahasına herkes tarafından anlaşılabilir, değerli bir eseri tanıtmaya çalışılacaktır.

Pek çok esere imza atan Sönmez'in özellikle İsa'nın Son Şamı adlı eserini ele almamızdaki başat sebep, onun iç dünyasınını yansıtan ve kaleminin gücünü en iyi temsil eden şiir olmasıdır. O, eserlerinde bağımsızlık, hürriyet ve vatan sevgisi gibi konulara genişce yer veren millî benliği zirvede olan bir şairdir. İran Azerbaycan'ında da İsa'nın Son Şamı şairi olarak tanınır. Bununla birlikte Azerbaycan Türkçesinin hem en duru hâlini kullanmış olup hem de sembolik ifadeler ile eserin üzerine düşündürücü bir üsluba sahip olması onu bu eseriyle çağdaşlarından bir miktar daha ayırt edici bir konuma taşır. Sönmez, daha önceki nesle mensup olmasına rağmen, 1979 İran Devrimi'nden sonraki kısmi serbestlikten faydalanarak eserlerini Azerbaycan Türkçesi ile yazmaya başlamıştır. Son şiirlerinde edebî anlamda ciddi bir gelişme gözlenir. "Babam Özü Gelecekdir" ve "Yeni Yollar Aşan Dağcl” "eserleri siyasi yönden değerlidir. Diğer eserleri arasında "Ăğı İller" ve "Garanguş Yazı Gözler" yer alır."

Şüphesiz İsa'nın Son Şamı, edebî ürünler içerisinde şairin en derin izi bırakan eseridir. Eserin okur ile buluşması, İran Türklerinin birçok şairinin içine dert olmuş gerçeklere ve yüz yıldır süre gelmiş İran yönetimi altındaki çeşitli etnik grupların devlet-toplum yapısı içerisinde fikrî hareketlerinin edebî yolla dile getirilmesine tanıklık etmesi demektir.

\section{Kerim Meşruteçi Sönmez ve İsa'nın Son Şamı}

\section{1. Kerim Meşruteçi Sönmez}

Şair, 23 Mart 1928 yılında Tebriz'de dünyaya gelmiştir. İkinci Dünya Savaşı'nın başladığı yıllarda Sönmez, 14 yaşında ilköğrenimini tamamlamıştır. Ailesinde süre gelen maddi sıkıntılar onu, bu yaşlarda babası İbrahim Bey'e maddi yardımda bulunmasına mecbur kılmıştır. Okul hayatından mahrum kalan Sönmez, 14-15 yaşlarında dokuma fabrikasında çalışmıştır. Maddi sıkıntılar çekse de daima öğrenim görme isteğini yüreğinde taşımış, gündüzleri çalışıp akşamları ise okumuş, Tebriz'de gece okullarında ortaokulunu tamamlamışır. 27 yaşında lise öğrenimini bitirdikten sonra Tahran

Ali Kafkasyal1, İran Türk Edebiyatı Antolojisi, (Erzurum: Atatürk Üniversitesi Yayınları, 2002, c. 3-6), 76. 
Üniversitesi Hukuk Fakültesinde yüksek öğrenimine başlamıştır. 1958 yılında Tahran Bankası'nda işe başlamıştır. 1961 yılında evlenmiş, biri kız biri de erkek olmak üzere iki çocuğu olmuştur. 34-37 yaşları arasında yüksek öğrenimine devam ederken bankada çalışmasını da sürdürmüştür. 1971-72 yıllarında Akbank'tan Bursalı Ertan Zıngır Bey'in de katılım gösterdiği Londra'daki Midlan Bank'ın altı aylık kursuna katılmıştır. 1972'de Londra'dan İran'a dönerken ilk kez Türkiye'ye gelmiş ve burada beş gün kalmıştır. 1972-1980 yılları arasında İran'da çalışmış olduğu bankanın tüm Türk dilli eyaletlerinde müdür olarak görev yapmıştır. 1981 yılında Tahran'a taşınmış ve o yıllarda birkaç banka birleşip Millet Bankası adını almıştır. Sönmez, aynı yılda çalıştığı bankadan emekli olmuştur. İki yıl sonra İran Çelik Sanayi Şirketi'nde işe başlamıştır. 1983-1988 yılları arasında iki çocuğu da Orta Doğu Teknik Üniversitesi’nde yüksek öğrenim görmüştür. İran Çelik Sanayi Şirketi'nden 2014 yılında emekli olmuştur. Genç yaşlarında, çocukların eğitim almasına büyük önem vermiş, çağdaş ve medeni milletlerin kökünün eğitime dayandığını öne sürmüştür. Bu konuda da kendi vatanında iki sınıflı okul açarak, çocuklara okuma-yazma ve millî düşünce tarzını öğretmeye çalışmıştır.

Şair, 1987 yılında Bakü'ye dostları tarafindan davet edilmiş ve burada büyük bir muhabbetle karşılanmıştır. Edebiyat camiasında da epeyce dikkati üzerine çekmiştir. 1989 yılında ise Türk dünyasının tanınan ve sevilen şairi Bahtiyar Vahapzade'nin girişimi ile "Qaranquş Yazı Gözler"2 adlı şiir kitabı Bakü'de basılmıştır. 40 yıl sonra Sönmez'in söylediği gibi vatanının diğer yarısına kavuşmak, onun içinde büyük bir coşku uyandırmış ve hasret gidermiştir. Yaşadığı sevincin diğer bir sebebi ise aynı dili konuşup ve aynı vatan sevgisini taşımalarından ötürüdür. Dolayısıyla bunu "Yaşa Taleyim"de şu sözleri ile dizeleri ile dile getirmiştir:

"Qırx illik hesrétlér qovuşan kimi,

Biz qucaqlaşırıq tapışan kimi,

Göy ulduz yağdırır kehkéşan kimi,

Duyğular geléndé cuşa, taleyim!”

Kerim Meşruteçi Sönmez, Qaranquş Yazı Gözler, (Bakü: Yazıcı Yayınları, 1989) 
Sönmez'in şair olarak tanınmasında ve geniş okuyucu kitlesinin ilgisini kazanmasında 1979 İran İslam Devrimi'nden sonra dünyaca ünlü Prof. Dr. Cevat Heyet'in ${ }^{3}$ şahsi girişimi ile yayıma başlayan ve şimdiye kadar da faaliyetine başarı ile devam eden "Varlık" dergisinin rolü büyüktür. Derginin yayına başladığg ilk yıllarda, büyük emekleri bulunan şairin çok sayıda edebî ve ilmî yazıları dergide yer almıştır. Bunların yanı sıra Üzeyir Hacıbeyov'un “Azerbaycan Halk Müziğinin Esasları” adlı eserinin ve Bahtiyar Vahapzade'nin “Atılmışlar” poemasının Arap harfli neşrini yapmıştır. Üstat Şehriyar'ın da "Haydar Baba'ya Selam” şiirini de Farsçaya tercüme etmiştir. $^{5}$

Sabir Emirov, "Sönmez'in Poeziyası", "Harareti Sönmeyen Ocak", 6 "Hasret Çelengi" adlı yazılarında; Xuraman Hümmétova "İsa'nın Son Şamı" ve "Qaranquş Yazı Gözler” adlı makalelerinde Sönmez'i Azerbaycan edebiyatının görkemli örnekleri olarak tanıtır. Mirza İbrahimov da yine Sönmez'in "Sensizlémişém" şiirini hususiyetle tahlil eder: "Sönmez Güney poeziyasında yüksek edebi-bedii değerli şiirlerin, dörtlüklerin, bayatıların, gazellerin, sanatkârlıkla yazılmış poemaların yazarıdır. Şüphesiz, poetik bakımdan edebî hareketin geçtiği yollarda şairin en derin iz bırakan kalem mahsulü 'İsa'nın Son Şamı' poemasıdır."”

Sönmez'in yeteneği, imge tasarımı, geniş dünya görüşü, kaleminin gücü felsefî tutumlu poemalarında daha açı ve yoğundur. Şüphesiz ki, onu halk içinde ve sanat dünyasında daha çok tanıtan eseri "İsa'nın Son Şamı"dır. Bu eser, onun sanat dünyasındaki kimliğidir. Bu eserdeki parlak idealar, insani fikirler, heyecan ile okuyanı sarsan, okuyucunun ruhuna işleyen muhakeme-

Prof. Dr. Cevat Heyet: İran Türk'ü, İran'da kalp cerrahisinin kurucusu ve Türkolog. Ayrıca bkz: Mehmet Rıza Heyet, "Bıçak ve Kalem Üstadı Cevat Heyet" Son Erişim: 12 Nisan 2020, https://www.turkyurdu.com.tr/yazar-yazi.php?id=320

4 Varlık: İran'da yayımlanan ilk Türkoloji dergisidir. 1979'da Cevat Heyet tarafından kurulmuş olup, 2015 yılından itibaren Ankara'da Mehmet Rıza Heyet tarafından yayım hayatına devam ettrilmektedir.

5 Sönmez'in hayatına ilişkin verilen bu bilgilere kendisiyle iletişime geçilerek ulaşılmıştır.

6 Sabir Emirov, Bu Kervanın Yolu Güney'edir, (Bakü: Nurlan Yayınları , 2007), 22.

7 Xuraman Hümmétova, “İsa'nın Son Şamı”, Azérbaycan Edebiyyatşünaslığ Problemléri, (Bakü, 1993)

8 "Ümidim haqdır, haqlıdır yolum: Kərim Məşrutəçi Sönməz", Son Erişim: 03 Mayıs 2020, http://azkurs.org/umidim-haqdr-haqldr-yolum-kerim-mesruteci-sonmez.html 
ler dikkati üzerine çekmektedir. ${ }^{9}$ İsa'nın Son Şamı, felsefî-didaktik niteliği ile Sönmez'in insanc1l ruhuna belirgin bir mükemmellik arz eder. Eserin hacimce büyüklügüü, onu şairin diğer eserlerinden farklı bir konuma taşır.

Sönmez ile bütünleşen, bizi onun engin hayal dünyasına taşıyacak olan ve ruhunun derinliklerinden gelen kendine ve halkına özgü duygu ve düşüncelerine tanıklık etmemizi sağlayacak olan İsa'nın Son Şamı'dır.

\section{2. İsa'nın Son Şamı}

Leonardo Da Vinci'nin ünlü yapıtı Son Akşam Yemeği tablosu üzerinde en çok çalışılan, merak edilen ve hayranlık uyandıran eserlerin başında geliyor. Öyle ki, eser üzerine yapılan çalışmaların ve keşfedilen sırların sonu gelmiyor. Çağları aşan bu yapıt daha önce pek çok hikâye ve rivayetlerle gündeme gelmiştir. Bunlardan en ünlüsünün altında Paulo Coelho'nın imzası bulunur. Sönmez de eserini Azerbaycan Türkçesinin anlatım olanağı ile tablonun hikâyesini şairane bir üslup kullanarak daha mühim bir amaçla kaleme almıştır. Bu eser dâhi bir ressam ile usta bir şairin buluşmasının özgün bir örneğidir.

Şairlerin sanat eserlerinde ekseriyetle ferdî hislerinin terennümü içinde olduklarını görüyoruz. Bu terennümde, şiiri oluşturan şekil ve ahenk unsurlarından geniş ölçüde yararlanmış olmaları sanat eserinin değerini arttırmaktadır. Sanatçı kullandığı kelimeleri özenle seçer ve bunlarla şiirini bir kanaviçe gibi işler. Sanat eserinin sırlarını ancak kendisine hususi sualler soranlara açacağını ifade eden Mehmet Kaplan, tahlil çalışmalarının önemini dile getirmektedir. ${ }^{10}$

Sönmez'in şiirinin kendine özgü dünyasına bu açıdan bakmakla, sanatçının söylemine ve ferdî psikolojisinin anahtarına ulaşmayı hedeflemekteyiz. Şair öncelikle diğer şiirlerinde olduğu gibi İsa'nın Son Şamı'nda bağımsızlık, insan ve vatan sevgisinini hümanist bir söylemle konu olarak seçmektedir. Ísa'nın Son Şamı adlı eserine ise akşamı ve güneşin batışını betimleyerek başlayan şair, kızıl renk ve onun diğer tonlarınının tasvirine şiirin genelinde genişce yer vermiştir. Sönmez, sanatçı yönü itibarı ile hep

\footnotetext{
$9 \quad$ Sabahi Genceli, “Ağır İller ve İsa'nın Son Şamı'na Bir Nazar”, Şiirimiz Zamanla Adımlayır-Edbiyatşünaslığa Göre Seçilmiş Yazılar Toplumu, (Ocak 2017), 91. Son Erişim: 03 Mayıs 2020, https://turuz.com/search?content=\&q=Genceli+Sabahi

10 Mehmet Kaplan, Şiir Tahlilleri, (İstanbul: Dergah Yayınları,1975), 5.
} 
kırmızı, ak ve kara renklerini kullanan bir kişiliğe sahiptir. Kırmızıyı kızıl, kan, ateş ve alev gibi kelimelerle ifade etmektedir. Şair, eserlerinde akşam ile gün doğumunu, alev ve kan kızıllığı ile kendi evrenini süslemektedir.

“Günün yorğun anlarında,

Q1zıl güneş dayanmadan,

Al şefeqli üfüqlerde,

Öz möhteşem varlığını

Tentene ilen çekmekdedir." ${ }^{11}$

Dış dünyaya ait olan su, güneş, yıldız ve ay kısaca bütün tabiat akşam vakti bambaşka bir görünümdedir. Şiirde bu anın şairin hayalinde uyandırdığ izlenimlerle yeniden biçimlendiği görülmektedir.

“İnce, zeri téllerini

Saçmış qizıl sancaqlara, “Él Gölü”nün üzerinde

Göm-göyerçin lepeleri

Bir-birine tikmekdedir.

Sanki güneş vedalaşır

Bir gécelik sefer üçün.

Dalısınca su çilerken, Ay söyleyir: Sağlam qayıt!

Ulduz déyir: Güle-güle!"12

Tabiat da umutsuz, bıkkın insan gibi batan güneşle beraber gecenin, karanlığın hüznünü yaşamaya hazırlanmaktadır. Yerini geceye bırakan güneş, burada her şeyin geçici ve insanın da varlığının tıpkı doğa gibi değişkenli-

\footnotetext{
11 Kerim Meşruteçi Sönmez, İsanın Son Şamı, (Tebriz: Neşre Endişe Yayınları, 2006), 7.

12 Sönmez, İsanın Son Şamı, 9.
} 
ğe mahkûm olduğunu simgeler. Bunu bilen ve yaşayan insanın niçin hırçın ve doyumsuz olduğu sorgulanır.

\author{
"Bilmem neden bu sert insan \\ El götürmür menemlikden, \\ Bu ebedî dolanışda \\ Ünsiyyeti göre-göre, \\ Uygunluğu bile-bile."13
}

Burada duyguların açıkça belirtilmediğini, birtakım sembollerle Sönmez' in gizli bir duyguyu ifadeye çalıştığını gözlemliyoruz. Bu yaklaşım, onun sembolik sanatın türlü yorumlara yol açan niteliğine bağlı kaldığını gösterir biçimdedir. Şiirdeki âhenk kulağımıza hoş gelirken, kelimelerle de gözümüzün önünde bir tablo çizilmiştir. Şiirde anlamdan ziyade kelimelerin söyleyiş biçimi dikkati çeker. Burada söz anlamın zarfıdır. Sönmez sade bir dil ve akıcı bir üslûpla yazmış olduğu şiirinde, anlama yoğunluk kazandırmıştır.

Vatan tabiatının muhteşemliği ve esrarengizliği içerisinde insan amaçlarının kusurları, şairin hassas yüreğinde bir itiraz ve isyan duygusunu uyand1rır. Dizelerine yansıyan şehir meydanında gördüğü dehşet verici olay onu derinden sarsar. Cezanın ve şiddetin hüküm sürdüğü bir yaşayışta, insanlık kötülüğün gölgesinde kalır. Din ve ahlâk kuralları altında yurttaşlara yaşatılan zulümler, insanlığın manevi baskısını ve vicdani sorumluluğunu hissettirir.

"Géçen hefte 'Miyana'da, ${ }^{14}$

Şehrin böyük méydanında,

Bir talésiz, yazıq kişi,

Birce qurtum çaxır üste

Şallaqlanıb rehmsizce.

13 Sönmez, İsanın Son Şamı, 13.

14 Miyana: Tebriz'in 187 km güneydoğusunda yer alan İran' da bir şehir. 
Doğrudan da İslam déyib:

Her Müselman, her zamanda,

Her mekânda, her ne qeder,

Her ne üçün,

Her kim ilen çaxır içse,

Gerek mütleq bu şekilde cezalansın?

Bugün, dünya milletleri,

Terbiyetle, mehebbetle,

En yırtıcı héyvanların xasiyyetin deyişdirir,

İnsanlarla qonuşdurur.

Sen hele de öyünürsen

İnsanları tapdamaqla?!"

Ceza ve zulüm ne kadar şiddetli olursa, zalimin kırbacı amacına o kadar istekli hizmet eder. Bunun sonucunda manevi açıdan sarsılır. Bu dizelerde şair esas düşüncesini okuyucuya yansıtır. "İnsanları ezmek ile övünenler" asıl kendileri cezaya ve zulme mahkûmdurlar. İnsan yüksek ve mukaddes bir varlıktır. Fakat hayatın eziyetleri ve azapları onu felâkete, gaddarlığa sürekler. Karanlık ve kötülük içerisinde beslenerek onu günaha, hırsızlığa, ahlâksızlığa, cinayete yönlendirir. Bütün saf duygularını ve iyiliğini, insanlığını kaybeder; manevi dünyasını yitirir.

Sönmez, öncelikle bu düşüncesini şiirinde ileri sürer. Daha önce giriş kısmında belirttiğimiz, dünyaca tanınmış Leonardo Da Vinci'nin “Son Akşam Yemeği” tablosunun hikâyesinden şair, ustalıkla ve sanatkârlıkla istifade eder. İnsanın yüreğinin derinliğine işleyen, didaktik bir anlatıyla hayatın iki yüzü; ak ve kara kadar zıt olan, gecesi ve gündüzü bir olmuş insanın, yoksul Renato'nun, çocukluğundan beri yetim ve ilgisiz kalmış, sıcak bir şefkate ihtiyaç duyan kadersiz bir gencin yüzünde bütün açıklığı ile görünür. Şair, bu zıtlıkların nasıl değiştiğini ve kaderin oyununu nasıl oynadığını ustaca ortaya koymaktadır. 
Renato'nun henüz hayatın acısı ile karşılaşmadığı zamanlarda, yüzü ay kadar aydınlık ve kalbi henüz bir su kadar duru ve temizdir. Gencin yüzündeki 1şık, gözlerindeki ilahî duruluk, masumluk ve saflık, duruşundaki nahiflik, bütün ruhunu saran hayat aşkı ve yaşama sevinci ressamı kendine çeker. O, sanki asıl İsa’yı bulmuştur.

\section{"Baxışından ismet yağır,}

Gülüşünden rehmet yağır,

Dâhiyane vügarı var,

Duruşundan izzet yağır,

Gören déyir: bu İsa'dır!

Ressam ondan ilham alır,

Mesiha'nın yaraşı̆̆ıı,

Güler üzün, me’sum gözün resm éleyir,

Duyguların renge qatıb, köçürür bir ağ ketene."15

Şüphesiz ki, tabiat insanı kusursuz yaratmıştır. Bu insan saf, mukaddes ve günahsızdır. O bütün manevi ve ahlâki değerlerin liyakatli taşıyıcısıdır. Onun simasına Tanrı'nın ışığı yansımaktadır. Bir başka deyişle, ilahî saflık insanın özünde, kalbinde ve ruhundadır. Bu, aslında Tanrı'nın kendisini, yarattığı varlık aracılığıyla dünyaya tanıtmanın bir yoludur. İsa'nın Son Şamı eserinde bu düşünce doğrultusunda sözü geçen aynı insanoğlunun hayattaki hem karanlık hem de aydınlık bir yaşayışı ele alınır. Eğer hayat, ahlâk ve adalet ile idare edilmiyorsa bunun ardında insanın, insanlıktan uzak düşmesi yatar. Renato'yu da uçuruma sürükleyen, adaletsiz dünyadır. Varlığını anlamlandırdığı, yaşamaya başladığı acemi çağlarında, babasının ölümü ile sarsılan Renato'nun kolu kanadı kırılır. Bundan sonra onun acı yaşamı başlar. Sevgi ve yardıma en çok ihtiyacı olduğu zamanlarda, herkes ona arkasını döner. Kimse elini uzatmaz. Yüreği hasret ile taşan Renato, doğru yolunu kaybeder. Aydınlığg aradığı hâlde, karanlık onu içine çeker.

\footnotetext{
15 Sönmez, İsanın Son Şamı, 23.
} 
"Béş gün sonra iş qurtarır,

Ressam onu mehribanca,

Güle-güle yola salır.

Lakin ressam,

Başqa modél dalısınca gezecekdi." ${ }^{16}$

İsa'nın aydınlık yüzünü temsil eden modeli bulan ressam, şimdi Yehuda'nın karanlık yüzünü temsil edecek modelin arayışına çıkar. Ancak aylar geçer, y1llar geçer, ressam çok arasa da bir türlü istediği yüzü bulamaz. Tablo tamamlanmak üzere herkesin tasviri tamamlansa da bir tek Yehuda eksik kalır.

İnançla aramaktan vazgeçmeyen ressam, ne zaman yorulsa kendine, "İnanç olan yerde, imkânsızlık yoktur.” sözünü hatırlatır. Sönmez bu dizelerde hayatı, boş bir tarlaya benzetir. İnançla bir tohum ekilirse karşıllı̆ında bin ekinlik hasat elde edilir. Bu hayata bir damla da olsa aşkı varsa insanın o damladan bir derya doğar önüne. Şair bu dizeler ile okuyucusuna vazgeçmemenin, umudun, direnmenin öğretisi ile yaklaşır.

Ressam gezerken dinlenmek için durur ve bir ağaç gölgesi bulur. Burada yemeğini yerken gözü de hep yoldadır.

"Böyük ressam yorgun-argın,

Bir ağacin kölgesinde

Uzanarken dirseklenir,

Mendesini açır yére,

Çöreyine su çileyir,

Derinden bir nefes çekir.

Kâinatın quruluşu, tebietin dolanışı

'Illliyete' bağlıdırsa,

16 Sönmez, İsanın Son Şamı, 27-29. 
İnsanların 'baş yazısı' mövhüm ise, İnandığım budur ancaq:

Açıq qapı bağlananda her terefden bağlanacaq.

Bağlı qapı açılanda her terefden açılacaq!”

Ressamın düşüncelere daldığı anı Sönmez, ustalıkla betimlemiştir. "İliyet" kavramı ile kâinatın varlığını kanunlara uygunluğuna dayandırır. İlliyet ve maluliyet kavramları, determinizm, yani nedensellik anlayışına dayanan felsefî bir yaklaşımdır. Olayların birbiri ile bağlı olması, her şeyin bir sebebi ya da her şeyin bir sebebe bağlanarak açıklanmasıdır. ${ }^{17}$ Sönmez'in dizelerinde bahsettiği gibi kâinatta her şey nedenlerin tasarrufunda ve idaresindedir.

"Qoca ressam, iller boyu bir çox yéri

Elek-velek élese de, indi onun

Yéddi göyde axtardığg,

Yér üzünde tapılmışdı."18

Tabiatta her şey bir nedene bağlandığ için ressamın da o kadar inançlı ve ümitli aramasına karşın sonucu da aradığını bulması olur. Karşısındaki kişi şeytanlığın tam heykelidir. Yüzündeki karanlık onu hem tiksindirir hem de sevindirir. Çünkü o kişi tam olarak Yehuda'nın simâsıdır. Gördügü kişi yı1larca tutsak kalmış, saçı sakalı perişan bir hâldedir. Yüzünden saçılan nefret ressamı sarsar. Sanki bakışlarından alev saçar. Şaşkınlığı ile düşünceleri arasında kaybolan ressam eline geçen bu firsatı değerlendirmek ister. Karşısındaki kişiyi yitirmeden ona atölyesinde model olmasını teklif eder. Çaresiz kişi sevinçle bu teklifi kabul eder ve hemen Yehuda'nın yüzü için model olur. Yehuda'nın gözlerini çizen ressam, o kişiyi konuşturur. Adam da geçmişinin rezilliğini bir övünç gibi anlatmaya başlar.

\footnotetext{
17 Rahmi Karakuş, "Neden Üzerine Düşünme”, Beytülhikme An International Journal of Philosophy 1, no.1, (June 201): 1-16.

18 Sönmez, İsanın Son Şamı, 32.
} 
"Kervanların yolun kesmek

Qatar-qatar develeri,

Matah dolu yükleri ilen vurub, çalmaq,

Çımxıranı xefelemek, menim üçün

Bir içim su, bir nefesdir.

Erli-ersiz qadınların

Namusuna göz q1cirtmaq,

Danqazlanıb, sine geren her kim olsa,

Köysün delib, dilin kesmek,

Menim üçün bir eylence, bir hevesdir."19

Yolunu kaybetmiş bu zalim kişi, el attı̆ğ her kötülüğün arkasında bir sebep arar. Onu bu yola sürükleyen kader ile eğlenir, hayattan intikam alır. "Vicdan nedir? Sorma menden!" diyerek kendi dünyasında anlaşılmaz olan bu sözü sorgular. Bilmese de mânâsını önüne kim gelse ona hediye eder.

Kişinin korkunç suçları ressamı hayrete düşürür. Ressam bir insanoğlunun yüreğinden vicdanın ve masumiyetin silinişine, bunun sonucunda yırtıcı bir hayvana dönüşmesine şaşkınlığını gizleyemez. İçinden ona karşı hem öfke hem de acıma duygusu geçer. Ancak hiçbir şeye bağlanmayan ve inanmayan böyle bir adamın sözleşmesine sadık kalması onu düşündürür.

"Yolu mütleq xetadırsa, bu, aydındır.

Lakin onun,

Öz ehdine, ilqarına mö'minliyi,

Yoldaşına, sırdaşına eminliyi,

Léonard'1 düşündürür."20

19 Sönmez, İsanın Son Şamı, 34.

20 Sönmez, İsanın Son Şamı, 35-36. 
Ressam, "Bir insan ne için insanlığını unutur?" sorgusu ile baş başa ka1ır. Burada Herakleitos'un Fragmanlar'ındaki, "Kendini tanıma ve ölçülü olma olanağ 1 her insanda bulunur." ${ }^{21}$ öğretisi ile yolunu kaybeden bu kişiye yaklaşılabilir. Ölçülülük ve ılımlılık insanın tutkularını denetlemesi ve doğasına uygun olarak bilgece bir yaşam sürmesi demektir. Bilgece bir yaşam sürmek için insanın önce kendini, insan olmanın doğasını tanıması ve bilmesi gerekir. Ancak insanların büyük bir çoğunluğu doğalarını tanımak ve ona uygun yaşamak istemezler. Burada kendini unutan insan bilge yaşamın tersine firtınalı bir yola sürüklenmiş ve kendini kaybetmiştir. $\mathrm{Bu}$ insanın tutsak geçen günlerine rağmen yine de özünde taşıdığı sorumluluk ve vefa hissiyat1, ressama onun geçmişinde saf ve duru bir insan olduğunu düşündürür. Duydukları onun hassas kalbini titretir ve gözyaşlarının akmasina engel olamaz.

"Ressamin da,

Gözyaşları, damc1-damc1,

Onun tüm ağ saqqalından

Eteyine damlayırdı.

Bélelikle Léonard'ın

Riyasızca axıtdığı gözyaşları,

O méhriban, şefeqetli baxışları,

Derman olub, teskin verir

O yazığın derin, köhne yarasına."22

Sönmez, sade ve isabetli tasvirleri ile yaşlı ressamın merhametli ve şefkatli bakışlarında, onu doğru yoldan saptıran, masumluğunu, çocukluğunu ve gençliğini hatırlatır. Bu gördüğü şefkat ile sıra sıra dizdiği o suçları anlatan adam durgunlaşır ve ölümlü günlerinde o uzun meşakatli geçmişin derinliklerinde kaybolur. Hasret ile geçmiş günlerini hatırlar:

\footnotetext{
${ }^{21}$ Herakleitos, Fragmanlar, çev. Cengiz Çakmak, (İstanbul: Kabalcı Yayınevi, 2005), 269.

22 Sönmez, İsanın Son Şamı, 39.
} 
"Varlığımı duyan zaman

Boya-başa çatmamışdım,

Atam öldü, bélim sindı.

Qohum-qonşu toplaşaraq,

Bir quru-boş 'baş sağllı̆ 1 '

Déyib, ona yas tutdular."23

Ardındaki dağ yıkılmış temiz yürekli bir gencin feryadına kimse yetişmez. Hayatın darbeleri onu amansız vurur ama güçlendirir. Yalnızlık ile baş başa kalınca anlar, ailesiz bir kimse aslında kimsesizdir. Artık mücadelesinde bir tek içindeki güç ona yardım edecektir. Ancak mazlum kişi el açar ve arayışa çıkar. Bilmez ki açılan her kapı aslında yolundan saptırandır.

Yolunu kaybetmiş adam, çok çalışır ve alın teri döker. Köle olmaktan kaçar ki babası gibi haysiyeti ve şerefi ile yaşasın. Ancak çaldığ tüm kapılar hep yüzüne kapanır. Her yerden eli boş döndüğünü gördükçe, yıkılır ve yaşamından usanır. Böyle buhranlı bir yaşayış ve tecrübesizlik onun ayakları altından tüm dünyayı çeker. Yere yığılır ve gözleri kapanır. Bir ara uyand1ğında gözünü açtığı yer zulüm ve fesatlık kucağı olur.

Sönmez'in edebî doygunluğu yüksek ve derin mânâlı dizelerinden de açıca anlaşıldığ gibi adamın genç iken düştüğü bu hatalı yol, onun aradığ1, arzu ettiği yol değildir. Belki de maddî ve manevî yoksunluk, insanlığa olan şüphesiz güveni onu bu uçurumlu yola sürüklemiştir. İçini az önce ince ince döken adam, biraz solukandıktan sonra tablosunu tamamlamakta olan ressamı da bu eziyetten sorumlu tutar:

"Ustad!

İndi, söyle görüm,

Mes'ul kimdir, ya hamımız?

Ya göydeki böyük Tanrı?

Ya onlar ki, Tanrı! déye

Qara zülmet yaradırlar?"24

23 Sönmez, İsanın Son Şamı, 40.

24 Sönmez, İsanın Son Şamı, 41. 
Diyerek, yaşlı ressamı birçok haklı ve mantıklı sorular ile baş başa bırakır. Leonardo onu dinledikçe içine sığamaz. Öyle ki onun yaşadığ 1 bu felaketlerin sorumluluğundan ressama da pay düşer.

"Mes'ul kimdir? Sensen, ya men?

Ya onlar ki, 'İsa' déyib, din adından,

Yaradıcı insanları, böyük, dahi âlimleri

Tongallarda yandırırlar?"25

Sönmez, tablonun hikâyesini şairane bir uslubla anlatırken, daima hikâyenin içeriğinden kendi itirazlarını dile getirmekte faydalanmıştır. Gelmiş geçmiş en etkili kitle kontrol silahı olan dinî inançlar, binlerce yıldır başarıyla kullanılmaktadır. Sönmez'in dizeleri de burada İran İslam Devrimi'nin sonrasında kırk yıllık süre boyunca devrimin değişen yüzü ve hâlen aynı otoriter rejimi bu yolla koruyan yönetime bir sesleniştir. İnsanların hak arayışına verilen cevapları, din bayrağı altındaki hükûmet tutumunu, kısıtlı özgürlük haklarını, ayak altında ezilen yaşamları ve buna karşı duran kim varsa her birini sindirenleri Sönmez, büyük bir itirazla kaleme alır. Ancak Sönmez, yine dönemin sansür ve sınırlı yayın yasaklarındaki esareti de dile getirir. En keskin eleştirisi, din ile bilim ve fenin gölgelenmesinedir:

"Böyük Tanrı déye-déye

Harda kültür ocağ 1 var,

Harda bilik çırağ 1 var,

Her yérden bir işıq gelir,

Tonqal çatıb, yandırırlar."26

Böylelikle ressam kendi işini tamamlar. Modele de bir kese para verir ve merhametle onu yolcu eder. Yıllarca yarım kalmış eserini tamamladığ 1 için rahat bir nefes alır. Uzun bir yoldan gelmiş gibi başını yastığa koyar ve uy-

25 Sönmez, İsanın Son Şamı, 41.

26 Sönmez, İsanın Son Şamı, 43. 
kuya dalar. Ressam güzel bir uykuda iken kapısı çalınır. Kapıyı açtığında karşısında daha önce gönderdiği modeli durur.

"Kişi onu selamlayır,

Döne-döne üzr isteyir,

Déyir: Ustad!

Zehmet olsa, bağışlarsan,

Bir sorgum var:

Seni Tanrı! Söyle görüm,

Sen o ressam déyilsen mi, ?

Otuz béşil...

Belke qirx il bundan evvel,

Meni, cavan yaşlarımda,

Atölyede eyleşdirdin.

Kime modél durduğumu unutsam da,

Ancaq bunu anıram ki,

Meni yola salan zaman

Bir kise de sikke vérib

'Sağ ol!' dédin, 'Yaşa!' dédin!’’27

Der ve cevabını almadan oradan uzaklaşır, gözden yiter. Yaşlı ressam hayret içinde kalır. Demek ki bu adam hem İsa'nın aydınlık yüzü hem de Yehuda'nın karanlık yüzü imiş. Şair bu iki zıtlı̆̆ın toplumsal sebeplerini ustalık ve sanatkârlıkla kaleme almıştır ve yaratıcılık yeteneğini eserine yansitmıştır.

Poemanın başlangıcında "Giriş" bölümü olduğu gibi sonunda da bir "Son Söz" bölümü vardır. Burada şair, tablonun hikâyesinden ibaret olan eserinin sonunda "Miyana kırbaççısını" hatırlatır. Şair okuyucusuna "Belleğiniz sağlam, yüzünüz ak, vicdanınız uyanık olsun." dilekleri ile bir de isteğini dile getirir:

27 Sönmez, İsanın Son Şamı, 43-44. 
"Miyana'dan yoluz düşse,

Sizi Tanr1!

Orada bir dayanarken,

Nağılımı

O insafsız şallaqçıya hediye vérin,

Bir oxuyub,

İşlerinde sayaq olsun." ${ }^{28}$

Şair buradan sonraki dizelerinde didaktik bir söyleme sahiptir. Okuyucusuna aktardığı düşüncelerini, itirazlarını tamamlarken bunca ahlaksız ve adaletsiz yaşayış sorunlarına temel yaklaşımları ile çözüm getirir. Onun lugatında doğru yol, adalet, özgürlük ve insanlık yer alır. Doğru yolu bulmada seçilecek yolun insanın kendine dönmesidir. İnsan ruhunu derinliklerinde, insan doğasının var oluşsal gereğinde yatan masumiyet, saflık ve duruluk çıkış için yegâne $1 s ̧ ı k$ kaynağıdır. Şairin hedef aldığı temel sorunlar çağdaş yaşamın tezatlıkları, kanunsuzlukları ve adaletsizlikleridir. Toplum yaşamı öyle kanunlarla idare edilmelidir ki insan, hürriyeti yaşasın ve geçici olan o kısa ömründe bir köleye dönüşmesin.

Şair, karanlığı eziyetsiz ve eli boş bir şekilde bulma çabasını cehalet ile bir tutar. Karanlık ile mücadelenin tek yolunu bilgi ve hür akıl ile bulur. Aydınlığın gücü ile ister yakın ister uzak olsun tüm gecelere güneş doğacaktır, anlayışına sahiptir.

Sönmez'in poeması boyunca anlatım gücünde başvurduğu ve zengin örnekler ile çeşitlendirdiği yöntemin başında kavramların zıtlığı gelmektedir. Bir kavram diğerinin varlığ 1 ile dile gelmekte ve buradaki çatışmalar ile asıl düşünce yansitılmaktadır. Yine esaret ve azadlık üzerine üst sınıfın konumu eleştirilir. Hegel'in "Köle-Efendi Diyalektiği" 29 olarak bilinen meşhur metninde kendi var oluş nedenini ötekinin var oluşuna bağlamak; bu köle için de efendi için de böyledir. Ancak köle, efendinin efendi olma nedeninin kendi varlığından kaynaklandığını fark ettiğinde bu varoluş çatlar ve çatışma doğar. Varlık kimliği Hegel'in köle-efendi diyalektinde yaptığı

\footnotetext{
28 Sönmez, İsanın Son Şamı, 47.

29 Hegel G. E. W., Lordship and Bondage, çev. J. B. Baillie, ( New York: 1967).
} 
çözümlemeye benzer şekilde, toplumsal bir sorundur. Yani poemadaki kişinin ya da toplumun varlığını kanıtlaması ve özgürlüğünü kazanması ancak diğerleriyle etkileşimi ve onlara baş kaldırışı ile gerçekleşir. Sönmez, bu konuda toplumunun okuyucu yoluyla bilinçlenmesinin, kendilerini tanımalarının ve tanımlayabilmelerinin yolu ile mümkün olabileceğini gösterir

\section{Fikrî ve Edebî Kişiliği}

Tebrizli Şair Kerim Meşruteçi Sönmez'in İsa'nın Son Şamı adlı eserin edebî tahlili ile amaçlanan, şairin aktarmak istediği düşünce ve duyguların 20. yüzyıl İran'1 çerçevesinde kavranması ve Sönmez'in bu düşüncelerini sanat yoluyla nasıl ifade ettiğini edebî ve fikrî bağlamda Azerbaycan Türkçesinin sunduğu imkânlar ve söz varlığı dâhilinde çözümlenmesidir.

Tebriz, İran'ın Doğu Azerbaycan Eyaleti'nin başkenti konumundadır. Tarihî ve kültürel mirası ile İran Türklüğünün merkezidir. Binlerce yıllık tarihî geçmişiyle İran siyasal ve sosyal yaşamında önemli bir yere sahiptir. Pek çok siyasi olayın cereyan ettiği dönemlerde Tebriz şehri başı çekerek millî uyanışta etkin rol oynamıştır. ${ }^{30}$ Özellikle 1906-1911 İran Meşrutiyet Devrimi $^{31}$ döneminde Tebriz, mücadelenin merkezi olmuştur. 1920'de Muhammet Hıyabani önderliğinde özgürlükçü “Azadistan" hareketinin de çıkış noktası olmuştur. İkinci Dünya Savaşı yıllarında Pişeveri önderliğinde Özerk Azerbaycan hükûmetine de ev sahipliği yapmıştır. Bu süreçte önemli reformlar gerçekleştirilmiş bunlardan en önemlisi de Azerbaycan Türkçesinin resmî dil ilan edilmesi olmuştur. Tebriz Üniversitesi kurulmuş ve Türkçe, matbu ve basın alanında özgürce kullanılmıştır. Bu süreç çok sürmeden 1 yıl sonra (1946) Tahran yönetiminin fermanı ile Türkçe kitaplar toplatılıp imha edilmiş ve Türkçe yasaklanmıştır. Bu durum, millî azınlıkların isyan duygusunu uyandırmış ve bu yasaktan duydukları derin üzüntüyü edebî yollarla dile getirme arzusunu uyandırmıştır. Ancak aralıkla artan yasaklar, ana dille üretilmiş eserlerin neşrine kati bir sınır çekmiştir. $^{32}$

30 Mehmet Akif Koç, “Modernleşme Sürecinde ‘İran Milliyetçiliği’ Yanlısı Tebrizli Bir Aydın: Ahmed Kesrevî- Hayatı, Şahsiyeti, Dünya Görüşü, Mücadelesi ve Eserleri”, Kadim Akademi SBD 3, no. 2, (Aralık 2019): 122-123.

32 Nesib Nesibli, Azerbaycan'da Kimlik Sorunu, (Bakü: Ay-Ulduz Yayınları, 1997), 154155. 
Tebriz'de, 1979 yılında İran Monarşi rejiminin sonunu getiren İran İslam Devrimi'nin fitili ateşlenmiş ve bütün ülkeyi sarmıştır. Devrim sonrası gelişen yeni düzende azınlıkların özerklik talepleri gündeme gelmiştir. Ancak İran yönetimi bu talepleri bölücü bir hareket olarak nitelendirmiştir. ${ }^{33}$ İran Anayasası'nda Tükçenin kullanılmasına dair yazılı bir serbestlik tanınmıştır ancak uygulamada hâlen yerel dillerin kullanımında bir kısıtlama söz konusudur. Yasaya göre, “Irran’ın resmî ve ortak dili Farsçadır. Bütün resmî belgeler, yazışmalar, metinler ve ders kitapları bu dil ve bu alfabeyle olmalıdır. Fakat, yerel ve kavmî dillerin basında ve kitle iletişim araçlarında kullanılması ve onların edebiyatlarının Farsçanın yanında okullarda ögretilmesi serbesttir." ${ }^{34}$ şeklinde dil kullanımı ibraz edilmiştir.

Kerim Meşruteçi Sönmez İran Azerbaycan'ında pek çok siyasal değişikliğe maruz kalmış, ana dili için mücadele edebilen Tebriz'in aydın kişilerinden olmuştur. Devrim sonrasında yayınlattığ 1 eserleri Türkçe olarak kaleme alınmış ve bu eserlerinde kullandığı metaforlar ile İran Türklerinin yukarıda verilmiş olan tarihî geçmişinden bugününe dek süre gelen mücadelelerini sanatı ile ifade etmiştir.

Eserlerini yaratan öznenin (ben) şiirindeki (ben) diyen kurmaca özneyle söylemin sorumluluğunu üstlenir. Böylelikle Sönmez, yarattığı söylem ile arasındaki öznellik/nesnellik, yakınlık/uzaklık ilişkilerini kendisi düzenlemiştir. Şair, söylem sürecinde zaman ve uzam içinde, dış dünya nesneleriyle şiirinde ilişki kurmuş ve kendisinden izler bırakmıştır. Yazınsal süreçlerde bu iki öznenin birbirine yaklaştığı hatta karıştığ 1 da olabilir. Bunun en çarpıcı örneğini Sönmez ortaya koyar. Eserinde özellikle dikkat çektiği kırbaç cezaları, onun 1979 yılından itibaren teokrasiyle yönetilecek yeni İran'ın getirdiği yasaklar ve cezaların yansımasıdır. Tüm bireylerin özellikle kadınların özgürlük haklarının teker teker ellerinden alındığ muhafizlarının toplumun her kesiminden insanın her hareketini kontrol eder hâle geldiği, mezhepçi fikirlerin toplumu ayrıştırdığı, düşünmenin, okumanın, kendi dilinde eğitim almanın, eğlenmenin, yazmanın yasak olduğu bir dönemde kendi vatanında yabancılaşan Sönmez, kurmaca öznesinde tüm bu esarete, yasaklara ve cezalara itiraz etmiştir. İşte tam burada yaratıcı özne ile kurmaca özne bir bütün olmuştur.

33 Bilgehan A. Gökdağ ve M. Rıza Heyet, “İran Türklerinde Kimlik Meselesi”, Bilig, no. 30, (Yaz 2004): 57-58.

34 Iran Anayasast, Farsça: قانون اساسى جمه اسلامى اير ان "Kanun-i Esasi Cumhuriye İslami İran”, (Tahran: İran Kültür Bakanlığ1 Yayınları, 1991), 26-27. 
Bir sanatsal uyaran olarak şiirde dil, ifade ve üslûp arasında oldukça güçlü bir ilişki bulunur. Dilin kullanılması, ifade ve üslûpla bir bütünlük gösterir. Sözcüklerin ifade biçimleri diğer etmenlerle birlikte şiirin ya da şairin üslûbunu oluşturur. Sanatçının okurun ve toplumun duygularını devindirmesi ve onlar üzerinde etki bırakması, onun sözcük seçimine ve dili kullanım şekline bağlıdır.

Kerim Meşruteçi Sönmez'in de edebî dünyasındaki sözcük seçiminde kendi kişiliği ve toplumcu anlayışı ile şekillenen psikolojik unsurları yer alır. Çağdaş şiir anlayışında görülen serbest çağrışımlardan yararlanma ve al1şılmamış bağdaştırmaları, edebî söz sanatlarından kendine özgü yaratımları Sönmez'in şiirinde önemli yer tutar. Şair, şiirinde çoğu kez imgelere, ikilemelere, deyimlere, özgün cinaslara ve birtakım kelime oyunlarına başvurmuştur. Onun felsefî yönlü bir şair olmasının altında özellikle üst bilinç ile ele alınan kavramları alt bilinçle sezdirme yolunu ustalıkla izlemesi yatar.

Anlam, bir sözcügün sözlükte verilen tanımından daha geniş, metnin içinde her okuyuşta yeniden oluşan bir kavramdır. Sözcüklerin sözlükte verilen anlamlar ne kadar genel ve değişmez ise yan anlamları da o kadar özel ve değişkendir. Şiirin anlam alanı yan anlamla zenginleşir, özgünleşir. Bir dile, bir kültüre, en önemlisi de bir şaire özgü olan yan anlamlar başka bir dilde ya da kültürde olmayabilir. Örneğin eski ismiyle Şahgölü olarak bilinen El Gölü'nü hiç görmemiş, Tebriz'in ev sahipliği yaptığı bu parkın kendine özgü çekiciliğene ve eşsiz manzaralarına tanıklık etmemiş biri için buranın çağrışımları son derece zayıf olacaktır. Ancak yalnız gösterge açısından bakıldığında bile, şiir, okuruna üzüntülerini hatta isyanlarını ve itirazlarını dile getirmek için çırpınan güçlü ve millî bir öznenin hüznünü, mücadelesini anlatır.

İsa'nın Son Şamı adlı eserin incelenmesinde öncelikli olarak metnin türü üzerine yapılan tespitlerden hareketle, şairin dil ve üslubu göz önünde tutularak diğer eserleri ile bağdaşıklık kurulmuştur. Yine aynı dönemde verilmiş eserlerin, toplumsal ve siyasî iletileri ile ortak bir paydada buluşan bu poema, İran Türklerinin sesi olmuştur. Öyle ki Sönmez, eserlerini asırlardır halkının ve yurdunun yüzleştiği dertlerine, yitirilenlere, yaşanan 1zdıraplara karşı yalnızca gördükleri ve yaşadıklarıyla, abartılardan uzak tüm gerçekliği ile yazmıştır. İran Türklüğünün tarihinin ve medeniyetinin kalbi olan Azerbaycan'ın ikiye bölünmesinden dolayı yoğun ızdırap duyan 
şair, daima kaleminde itiraz sorumluluğunu taşımıştır. Onun sanatı ile dile gelen bu eser okuyucusunu, düşündürerek ve sorgulayarak İran Türklügünün geçmiş ve gelecek tüm sorunlarına dâhil eder.

Halk için yazılan tüm eserlerde olduğu gibi, Sönmez'in eserlerinde de son derece yalın bir dil kullanılmıştır. Yabancı kökenli sözcük oranı düşüktür. Ancak Azerbaycan Türkçesinin söz varlığ dikkate alındığında dile yerleşmiş olan Farsça ve Arapça kelimelerin yerleşik olanlarından yararlanma da söz konusudur. Bu durumu, sözcüklerin halk ağzına yaklaştırılması olarak açıklamak mümkündür.

\section{Sonuç}

Kerim Meşruteçi Sönmez, Çağdaş Azerbaycan Türk Edebiyatında edebî ve sanat yönü yüksek şiirlerin usta şairi olarak tanınmıştır. Onun geniş okuyucu kitlesine ulaşmasında merhum Prof. Dr. Cevat Heyet'in girişimleri ile 1979 yılında yayın hayatına başlamış olan Varlık dergisinin rolü büyüktür. Dergide edebî ve ilmî faaliyetlerinin yanı sıra pek çok şiiri yayınlamıştır. ${ }^{35}$ Onun kimliği olarak anılan eseri Ísa'nın Son Şamı, edebî ürünleri içerisinde en çok dikkati çeken şiiridir.

Sönmez'in şiirlerine dair elde ettiğimiz tüm bilgilerin 1şı̆̆ında, onun, yap1 ve içeriğe dayalı yönleri, kendine has bir şekilde kullanmış olduğunu söyleyebiliriz. Bununla birlikte işlediği tema ve dönemin getirdiği dil anlayışı doğrultusunda gelenek ve yeniden uzak kalmamış serbest şekilli ve vezinli şiirler de yazmıştır. Her zaman, geçmişin izini sürmüş, özellikle Azerbaycan'1n bütünlüğüne ve millî hürriyete hasret ve özlem duymuştur.

İsa'nın Son Şamı eserinin en önemli özelliklerinden biri de iç huzursuzluğunun, özlemin ve halkının arzularının, kendi yurdunda bir milletin ötekileştirilmesinin temsil edilişidir. Sönmez, bütün bu düşüncelerini imgesel bir dil ve üslupla ifade edebilmiştir. Şairin asıl amacı az sözle çok şey anlatma ve görünenin arkasındaki görünmeyen gerçeklikleri göstermektir.

Eser, Azerbaycan Türkçesinin en yalın hâli ile yaratılmış olmasına karşın olgun ve donanımlı bir şiirdir. İfade olgunluğu, imge kültürü ve zenginliği,

35 M. Rıza Heyet, “Üstât Kerim Meşruteçi Sönmez'den Yeni Armağanlar”, Varlıq 2, no. 5-6, (Kış 2016): 65-71. 
dildeki dize mimarisi bakımından usta bir şairin elinden çıkmış olduğu açıkca görülmektedir. Şiir, anlam derinliğine sahip olan ve yaşamın her kesitini içinde barındıran bir yapıdadır. Bunu sağlayan da çağrışım değeri yüksek imgelerdir. Şairin her bir imgesi karşıtlıklardan beslenir.

Eserlerinde inanç, duygusallık ve realite iç içedir. Sönmez için toplumcu bir şair demek yerinde olacaktır. Çünkü o, yaşadığı toplumun gerçeklerinden etkilenen, onun sorunlarına ilişkin çözümler üretmeye çalı̧̧an millî bir şairdir. Şair, birey-toplum ilişkileri çerçevesinde, toplumun içinde bulunduğu sıkıntılara sanatçı hassasiyetiyle yaklaşmıştır. Sönmez'e göre karanlıktan aydınlığa giden yol insanın özünde keşfedilmek üzere bulunmaktadır. Mücadele ve inanç gereksinen tek ihtiyaçtır. Şiir, Sönmez için bir itiraz, isyan duygusunun seslenişidir. Öyle ki bu sesleniş onun ana dili ve gelecek kaygısını taşır. Bu sebeple Sönmez, gelecek nesile Varlığım şiirindeki vatan sevgisini şu dizeleri ile özetler:

\section{"Dilim-dilim doğra quzıl almanı,}

Ver her gelén yesin ondan bir dilim.

Üç kelmédir varlığımı bildirén,

Bir veténim, bir menliyim, bir dilim.. "36

\section{Kaynakça}

Aydoğan, Yaşar, Azerbaycan-Türkiye Türkçesi Büyük Sözlük 1-2, İstanbul: Beşir Yayınevi, 1999.

Çakmak, Cengiz, Herakleitos Fragmanlar, İstanbul: Kabalc1, Kasım 2009. Emirov, Sabir, Bu Kervanın Yolu Güney'edir, Bakü: Nurlan Yayınları , 2007.

Gökdağ, Bilgehan A. ve Mehmet Riza Heyet, "İran Türklerinde Kimlik Meselesi”, Bilig, no. 30, (Yaz 2004): 51-82.

Heyet, M. Rıza, Üstât Kerim Meşruteçi Sönmez'den Yeni Armağanlar, Varlıq 2, no.5-6, (Kış 2016): 65-71.

36 Kerim Meşruteçi Sönmez, Şeh Muncuğu, (Tebriz: Neşre Endişe, 2016), 11. 
Hümmétova, Xuraman, “İsa'nın Son Şamı”, Azérbaycan Edebiyyatşünasliğg Problemléri, Bakü: 1993.

Iran Anayasası, Farsça:قانون اساسى جمهورى اسلامى ايران, "Kanun-i Esasi Cumhuriye İslami İran", Tahran: İran Kültür Bakanlığı Yayınları, 1991.

Kafkasyalı, Ali, Iran Türk Edebiyatı Antolojisi, Erzurum: Atatürk Üniversitesi Yayınları, c. 3-6, 2002.

Kaplan, Mehmet, "Şiir Tahlilleri”, İstanbul: Dergah Yayınları, 1975.

Karakuş, Rahmi, "Neden Üzerine Düşünme”, Beytülhikme An International Journal of Philosophy 1, no.1, (June 201): 1-16.

Koç, Mehmet Akif, "Modernleşme Sürecinde ‘İran Milliyetçiliği' Yanlısı Tebrizli Bir Aydın: Ahmed Kesrevî-Hayatı, Şahsiyeti, Dünya Görüşü, Mücadelesi ve Eserleri", Kadim Akademi SBD 3, no. 2, (Aralık 2019): 115-155. Mehdibeyova, Mahmizer, Kerim Meşruteçi Sönmez ve Onun 'Şeh Muncuğu'Kitabı Hakkında Birkaç Söz, Bakü: Elm Yayınları, 2003.

Mehdibeyova, Mahmizer, "Vatan, Millet ve Edebiyat Sevdalısı: Kerim Meşruteçi Sönmez”, Bakü: 525. Gazete, Temmuz 2018.

Nesibli, Nesib, Azerbaycan'da Kimlik Sorunu, Bakü: Ay-Ulduz Yayınları, 1997.

Sönmez, Kerim Meşruteçi, İsa 'nın Son Şamı, Tebriz: Neşre Endişe Yayınları, 2006.

Sönmez, Kerim Meşruteçi, Şeh Muncuğu, Tebriz: Neşre Endişe Yayınları, 2016.

Sönmez, Kerim Meşruteçi, Qaranquş Yazı Gözler, Bakü: Yazıcı Yayınları, 1989.

\section{Internet Kaynakları}

Azkurs. "Ümidim haqdır, haqlıdır yolum: Kərim Məşrutəçi Sönməz", Son Erişim: 03 May1s 2020, http://azkurs.org/umidim-haqdr-haqldr-yolumkerim-mesruteci-sonmez.html 
Genceli, Sabahi, “Ağır İller ve İsa'nın Son Şamı’na Bir Nazar”, Şiirimiz Zamanla Adımlayır-Edbiyatşünaslığa Göre Seçilmiş Yazılar Toplumu, (Ocak 2017), Son Erişim: 03 May1s 2020, https://turuz.com/search?conte $\mathrm{nt}=\& \mathrm{q}=$ Genceli + Sabahi

Heyet, M. Rıza, "Bıçak ve Kalem Üstadı Cevat Heyet", Son Erişim: 12 Nisan 2020, https://www.turkyurdu.com.tr/yazar-yazi.php?id=320 